\title{
Yaşlı Diyabetik Hastalarda Malnutrisyonun Klinik Sonuçları ve Önemi
}

\author{
The Clinical Implications and Importance of Malnutrition in Elderly Diabetic Patients
}

${ }^{1}$ Saadet Koç Okudur, ${ }^{2}$ Pınar Soysal

${ }^{1}$ Manisa Sehir Hastanesi, Geriatri Bilim Dalı,, Manisa, Türkiye

${ }^{2}$ Bezmialem Üniversitesi Tip Fakültesi, Geriatri Bilim Dalı, İstanbul Türkiye

Correspondence:

Saadet KOÇ OKUDUR

Manisa Şehir Hastanesi, Geriatri

Bilim Dalı,, Manisa, Türkiye

e-mail: saadetkoc7@hotmail.com

\section{Özet}

Diabetes mellitus ve malnutrisyon, yaşlı hastalarda sık görülen sağlı problemleridir. Her ikisi de çok sayıda olumsuz sağlık durumlarıyla ilişkilidir. Çalışmamızın amacı, yaşılı diyabetik hastalarda malnutrisyon ile ayrıntılı geriatrik değerlendirme parametreleri arasındaki ilişkiyi değerlendirmektir. Kesitsel araşıırma tasarımı kullanıldı. Çalışmaya geriatri polikliniğine başvuran $\geq 65$ yaş, 506 diyabetik hasta dahil edildi. Hastaların demografik verileri, komorbiditeler, kullanılan ilaç sayısı, üriner inkontinans, ortostatik hipotansiyon varlığı ve laboratuar tetkikleri kaydedildi. Tüm hastalara ayrıntılı geriatrik değerlendirme yapıldı. Nörokognitif değerlendirme için Mini Mental Durum Değerlendirme testi (MMSE), duygu durum değerlendirmesi için Geriatrik Depresyon Skalası (GDS), fonksiyonellik değerlendirmesi için Temel Günlük Yaşam Aktiviteleri (TGYA) ve Enstrümantal Günlük Yaşam Aktiviteleri (EGYA) ölçekleri, yürüyüş ve denge fonksiyonları değerlendirmesi için Tinetti Denge ve Yürüme Testi ile Kalk ve Yürü testi (KYT), uyku durumu değerlendirmesi için Uykusuzluk Şiddet İndeksi (UŞİ) ve kas gücü için el kavrama gücü (EKG) testi dosya verileri kullanıldı. Çalışma grubu Mini Nutrisyonel Değerlendirme skorları $>23,5,17-23,5$ ve $<17$ olması sırasıyla normal nutrisyon, malnutrisyon riski ve malnutrisyon olarak kategorize edildi. Katılımcıların yaş ortalaması $76,86 \pm 6,97$ yl ve \%74,7'si kadın idi. Normal nutrisyonel durum, malnutrisyon riski ve malnutrisyon prevalansı sirasılla \%60,8, \%30,43’ü ve \%8,7 idi. Ayrıntılı geriatrik değerlendirme parametreleri gruplar arasında lojistik regresyon analizine göre değerlendirildiğginde malnütrisyon olan grupta TGYA, EGYA, Tinetti yürüme ve denge skorları, MMSE ve EKG skorları anlamlı olarak düşük iken, GDS, UŞI ve KYT skorları anlamlı olarak yüksek saptandı $(\mathrm{p}<0,05)$. Yaşlı diyabetik hastalarda malnütrisyon fonksiyonel gerileme, yürüme-denge bozuklukları, kognisyon ve duygu durum bozuklukları, el kavrama gücünde azalma ve uyku bozuklukları için bir risk faktörüdür. Yaşlı diyabetik hastalarda diyabet tedavi ilkeleri gözetilirken nutrisyonel değerlendirmenin de göz önünde bulundurulması gerekmektedir.

Anahtar Kelimeler: Diyabetes mellitus; malnutrisyon; ayrıntılı geriatrik değerlendirme; yaşlı

\section{Abstract}

Diabetes mellitus and malnutrition are common health problems in older adults. Both are associated with numerous adverse health conditions. The aim of our study is to evaluate the relationship between comprehensivez geriatric assessment parameters and malnutrition in elderly diabetic patients. A cross-sectional study design was used. A total of 506 diabetic outpatients aged $\geq$ 65 years were included. Demographic data, comorbidities, number of drugs used, urinary incontinence, orthostatic hypotension and laboratory tests were recorded. All patients underwent comprehensive geriatric assessment. Mini mental state examination (MMSE) test was used for neurocognitive assessment, Geriatric Depression Scale (GDS) for mood assessment, Basic Activities of Daily Living (BADL) and Instrumental Activities of Daily Living (IADL) scales for functionality assessment, Tinetti Balance and Gait Test and Time up and go test (TUG) for gait and balance assessment, Insomnia Severity Index (ISI) for sleep status assessment and hand grip strength for muscle strength assessment. Mini Nutritional Assessment (MNA) scores $>23.5,17-23.5$, or $<17$ were categorized as normal nutritional status, malnutrition risk, and malnutrition, respectively. The mean age of the participants was $76.86 \pm 6.97$ years and $74.7 \%$ were women. Prevalence of normal nutritional status, malnutrition risk, and malnutrition were $60.8 \%, 30.43 \%$, and $8.7 \%$, respectively. Comprehensive geriatric assessment parameters were evaluated according to logistic regression analysis between the groups. BADL, IADL, Tinetti walking and balance scores, MMSE and hand grip strength test scores were significantly lower in the malnourished group, while GDS, ISI, and TUG scores were significantly higher $(\mathrm{p}<0.05)$. Malnutrition is a risk factor for functional decline, gait-balance disorders, cognition and mood disorders, decreased hand grip strength and sleep disorders in elderly diabetic patients. Nutritional assessment should be considered while evaluating elderly diabetic patients for diabetes treatment principles.

Keywords: Diabetes mellitus; malnutrition; comprehensive geriatric assessment; older adults 


\section{Giriş}

Tip 2 Diyabetes Mellitus (DM) tüm dünyada yaygın olarak görülen önemli bir halk sağlığ1 sorunudur (1). Prevalansı yaşam süresinin uzamasıyla doğru orantılı olarak artış gösteren DM'nin yaşlı hastalarda yönetimi gençlere göre daha zordur (2). Örneğin, 65 yaş üstü diyabetik yaşlı hastalar, genç diyabetik hastalarla ile karşılaştırıldığında; yaşlılarda mikrovasküler komplikasyon gelişme riski benzer olmakla birlikte makrovasküler komplikasyonlar açısından mutlak riskleri, diyabetik genç hastalara göre önemli ölçüde yüksektir (3). Fiziksel aktivite, beslenmenin düzenlenmesi ve ilaç tedavisi kombinasyonlarını içeren iyi bir metabolik denetim, hastalığın progresyonunu geciktirmekte ve komplikasyon oranını azaltmaktadır. Fakat tedavinin olmazsa olmazlarından olan yaşam tarzı değişikliklerinin başında gelen fiziksel aktivitenin arttırılması, yaşlılarda sık görülen osteoartirit, düşme korkusu ve ortostatik hipotansiyon gibi durumlardan dolayı sıklıkla etkin bir şekilde gerçekleştirilememektedir (3). Yaşlilarda görülen polifarmasi, demans, geriatrik depresyon ve tremor gibi geriatrik sendromlar, hastaların ilaç uyumunu ya da insülin tedavisinin uygulanmasını olumsuz etkileyebilir $(2,4)$. Diğer yandan optimum glukoz regülasyonunu sağlama amaciyla gelişsebilecek hipogliseminin yaşlilarda düşme ve buna bağlı kırıklar, hospitalizasyon, kardiyovasküler olaylar ve tüm bu nedenlere bağlı mortalitede artışa sebep olabilmesi yaşlı diyabetik hastaların komplikasyon gelişmeden tedavi edilmesini zorlaştırmaktadır (5).

DM'nin yönetimindeki en önemli faktörlerden biri diyet modifikasyonudur. Ancak, malnutrisyon, malnutrisyon riski ve mikronutrient eksiklikleri zaten yaşlılarsa sık görülmektedir (6). Yaşlanmayla birlikte fizyolojik olarak azalan organ fonksiyonları, psikolojik, sosyal ve ekonomik değişiklikler bu hastalarda beslenme bozukluklarına yol açabilir. Malnutrisyon mevcut tıbbi tabloyu şiddetlendirmekte, hastanede kalış süresini, maliyeti ve ölüm oranını daha da artırmaktadır (7). 65 yaş üstü diyabetik hastaların $\% 26$ 'sinda malnutrisyon görülebilmektedir (8).
DM'nin kendisi, diyabetle ilişkili komplikasyonlar ve diyabet tedavisinde kullanılan ilaçlar hastalarda beslenme durumunu bozarak malnutrisyona neden olabilir. Özellikle yaşı hastalarda pankreas rezervinin azalmasıyla birlikte eksilen insülin hormonu, iskelet kasında glikoz kullanımını bozmakta, yağ ve kas yıkımını artırmakta ve buna bağlı gelişen ketozis ise mide bulantısı ve anoreksiye yol açarak malnutrisyona katkıda bulunmaktadır (9). Bunun yanında birçok yaşlı diyabetik hasta kilo kontrolü için katı ya da uygunsuz diyet yaparak malnurisyon gelişimine zemin hazırlamaktadır (10). Bildiğimiz kadarıyla literatürde yaşlı diyabet hastalarının beslenme ve bununla ilgili klinik durumunu değerlendiren çok az sayıda çalışma vardır.

Çalışmamızın temel amacı, geriatri polikliniğe başvuran yaşlı diyabetik hastalarda malnütrisyon prevalansını araştırmak ve malnutrisyon ile ayrıntıl1 geriatrik değerlendirme parametreleri arasındaki ilişkiyi değerlendirmektir.

\section{Gereç ve Yöntem}

\section{Hasta Seçimi}

Çalışma için Kasım 2019-Ocak 2021 tarihleri arasında Bezmi Alem Üniverisitesi Tip Fakültesi Hastanesi Geriatri Polikliniği'ne başvuran, 65 yaş ve üstü, ayrıntılı geriatrik değerlendirme yapılmış olan ve çalışma dizaynına uygun olan 506 diyabetik hastanın dosyalar1 retrospektif olarak incelendi.

\footnotetext{
$\checkmark$ Dişlama Kriterleri

$\checkmark 65$ yaşın altında olanlar,

$\checkmark$ Çalışmaya katılmayı reddedenler,

$\checkmark$ Terminal hastalığı olanlar,
}

Bireyin genel sağlık durumunu bozabilecek ciddi hastalığı olanlar (Örneğin; akut serebrovasküler hastalık, sepsis, gastrointestinal kanama, akut böbrek yetmezliği, akut koroner sendrom, akut karaciğer yetmezliği, akut solunum yetmezliği, akut enfeksiyonlar, kanser gibi)

Muayene sırasında iletişimi ve komutları anlamayı engelleyen ileri derecede demans1 
veya ileri derecede görme ve işitme bozukluğu olan hastalar,

Alkol ve/veya madde bağımlılığı olanlar çalışmadan dışlanmıştır.

\section{Hasta özellikleri}

Hastaların demografik verileri (yaş, cinsiyet), mevcut kronik hastalıkları (hipertansiyon, kronik obstruktif akciğer hastalığı, konjestif kalp yetmezliği, kronik böbrek yetmezliği, osteoartrit, iskemik kalp hastalığı, tiroid hastalığ , serebrovasküler olay, periferik arter hastalığı), kullanılan ilaç sayısı, son bir yıl içindeki düşme sayısı, yatarken ve ayağa kalınca ölçülen sistolik ve diyastolik kan basınc1 ölçümleri hasta dosyalarından kaydedildi. Vücut kitle indeksi (VKI), kilogram cinsinden vücut ağırlığının, metre cinsinden vücut boyunun karesi $(\mathrm{kg} / \mathrm{m} 2)$ değerine bölünmesiyle hesaplandı.

\section{Ayrıntılı Geriatrik Değerlendirme (11)}

Hastalara ayrıntılı geriatrik değerlendirme kapsamında uygulanmış olan nörokognitif değerlendirme için MMSE, duygu durum değerlendirmesi için Geriatrik Depresyon Skalas1 (GDS) (12), fonksiyonellik değerlendirmesi için Temel Günlük Yaşam Aktiviteleri Ölçeği (TGYA) ve Enstrümantal Günlük Yaşam Aktiviteleri (EGYA) ölçekleri (11), yürüyüş ve denge fonksiyonları değerlendirmesi için Tinetti Denge ve Yürüme Testi ile Kalk ve Yürü testi, uyku durumu değerlendirmesi için Uykusuzluk Şiddet İndeksi (13) ve el kavrama gücü (14) verilerine hasta dosya kayıtlarından ulaşılarak kayıt edildi. Üriner inkontinans, idrar yolu enfeksiyonu olmaksızın son 3 ayda istemsiz idrar kaçırma olarak tanımlandı (15). Ortostatik hipotansiyon, oturur veya sirt üstü yatar pozisyondan ayağa kalkıldıktan 3 dakika sonra ölçülen kan basıncında sistolik kan basincinda $\geq 20 \mathrm{mmHg}$ ve/veya diyastolik kan basıncinda $\geq 10 \mathrm{mmHg}$ düşüş olarak tanımlandı (16). Jamar el dinamometresi ile ölçülen el kavrama gücünün (ortalama 3 ölçüm) erkeklerde $<28$ kg, kadınlarda $<14 \mathrm{~kg}$ olması düşük kas gücü olarak tanımlandı (14).

\section{Nutrisyonel Değerlendirme}

MNA-K1sa Form skorları $\geq 12$ olsa bile tüm hastalarda malnütrisyon riskini saptamak için Mini Nutritional Assessment (MNA) yapıld1. Toplam puan $>23,5,17-23,5$ veya $<17$ skorları sirasiyla normal nutrisyonel durum grubu (Grup 1), malnütrisyon riski olan grup (Grup 2) ve malnütrisyon grubu (Grup 3) olarak kabul edildi. MNA testi basit ölçümlerden ve 10 dakikadan kısa sürede tamamlanabilen 18 kısa sorudan oluşur. MNA testindeki sorular; vücut kitle indeksi, kilo kaybı, kol çevresi ve baldır çevresi ile ilgili antropometrik ölçüm soruları, genel değerlendirme (yaşam tarzı, ilaç tedavisi ve mobilite ile ilgili 6 soru), diyet anketi ve subjektif değerlendirme (yemek sayıs1, yiyecek ve siv1 alım1, beslenmenin özerkliği, sağlık ve beslenmenin kendi algısı ile ilgili 8 soru) (17) sorularından oluşmaktadır.

\section{Laboratuvar Bulgulart}

Hastaların biyokimyasal, metabolik ve beslenme durumunu değerlendirmek için bazı laboratuvar testleri yapıldı. Tiroid uyarıc1 hormon (TSH), kolesterol düzeyleri, serum glukoz, hemoglobin $(\mathrm{Hb})$ ve $\mathrm{HbA1c}$ düzeyleri için laboratuvar kayıtları değerlendirildi. Tüm bu biyokimyasal testler, Diagnostic Modular Systems oto analizörü (Roche E170 ve P-800) kullanılarak yapıldı.

\section{B12 Vitamini, Folat ve D Vitamini değerlendirmesi}

Yetersiz alımın biyokimyasal kanıtlarını ve metabolik durumun değerlendirmek için, en az 8 saatlik açlıktan sonra sabah kan örnekleri alındı. Serum B12 vitamin eksikliği, B12 düzeyi $<200 \mathrm{pg} / \mathrm{mL}$ olarak değerlendirildi (18). Folat eksikliği folat düzeyi $<3 \mathrm{ng} / \mathrm{mL}$ olarak değerlendirildi (19). Kan örneği alındıktan sonra jel tüpler 1 saat içinde santrifüj edildi ve serum vitamin $\mathrm{D}$ analizi için $\quad-20^{\circ} \mathrm{C}^{\prime} \mathrm{de} \quad$ saklandı. 25(OH)D radyoimmünoanaliz yöntemi kullanılarak ölçüldü. $25(\mathrm{OH}) \mathrm{D}<30 \mathrm{ng} / \mathrm{mL}$ olan hastalarda D vitamini eksikliği olduğu kabul edildi (20).

\section{Çalışmanın Etik Boyutu}

Çalışma, Bezmi Alem Üniverisitesi Tıp Fakültesi Hastanesi Girişimsel Olmayan 
Arastırmalar Etik Kurulu'nun 15/01/2020 tarih 97706721-900 protokol nolu kararı ile uygun bulunmuş ve Helsinki Deklarasyonu ile uyumlu olarak yürütülmüştür. Çalışmaya dahil edilen katılımcılardan veya yasal vasilerinden bilgilendirilmiş gönüllü olur formu alınd.

\section{Istatistiksel Analiz}

Çalışmada istatistiksel analizler için IBM SPSS istatistik 22.0 programı kullanılmıştır. Çalışma verileri değerlendirilirken tanımlayıcı istatistiksel yöntemler (ortalama, standart sapma, medyan, frekans) kullanıldı. Verilerin normal dağılımını değerlendirmek için çarpıklık ve basıklık değerleri Shapiro-Wilk testi ile birlikte kullanılmıştır. Normal dağılım gösteren ikiden fazla değişkeni karşılaştırmak için tek yönlü ANOVA testi kullanılırken, normal dağılım göstermeyen ikiden fazla değişkeni değerlendirmek için Kruskal Wallis testi kullanıldı. Değişkenler arasındaki ilişkiyi değerlendirmek için ki-kare testi kullanıldı. Veriler arasındaki korelasyonu değerlendirmek için normal dağılım gösteren veriler için pearson korelasyon analizi, normal dağılım göstermeyen veriler için spearman korelasyon analizi kullanıldı. Yaş etkisi ortadan kaldirılarak, normal nutrisyonu olanlarla malnutrisyon riski; malnutrisyon ve malnutrisyon ve malnutrisyon riski olan gruplar arasında, ayrintılı geriatrik değerlendirme parametreleri açısından farkl11ı devam edip edilmediği lojistik regresyon analizi ile ayrı ayrı değerlendirildi. Sonuçlar \%95 güven aralığında ve anlamlılık $\mathrm{p}<0,05$ düzeyinde değerlendirildi.

\section{Bulgular}

Çalışmaya dahil edilen 506 hastanın yaş ortalaması $76,86 \pm 6,97$ yıl idi. Çalışmaya dahil edilen 506 diyabetik hastanın yaş ortalamas1 76,86 $\pm 6,97$ y1l idi. Hastaların \%74,7'si kadın, \%25,3'ü erkekti. Çalışma grubunun MNA skorlarının ortalaması 23,68 $\pm 4,16$ idi. Kat1lımc1ların $308^{\prime}$ inde $(\% 60,8)$ normal nutrisyonel durum mevcut iken 154'ünde $(\% 30,43)$ malnutrisyon riski ve 44 'ünde $(\% 8,7)$ ise malnutrisyon mevcut idi.

MNA skor gruplarına göre bakıldığında, hipertansiyon, iskemik kalp hastalığ ve kronik obstrüktif akciğer hastalığ siklığ1 açısından gruplar arasında anlamlı fark tespit edilmez iken $(p>0,05)$, konjestif kalp yetmezliği ve kronik böbrek hastalığı s1klığ1 malnütrisyonu olan hastalardan oluşan Grup 3 'te anlamlı şekilde yüksekti $(\mathrm{p}<0,05)$. MNA grupları ile yaş, ilaç sayısı, BMI ve laboratuvar verileri arasındaki ilişki Tablo 1'de gösterilmiştir. MNA grupları ile geriatrik değerlendirme parametreleri arasındaki ilişki Tablo 2'de gösterilmiştir. Yaş etkisi ortadan kaldırılarak, normal nutrisyonu olanlarla malnutrisyon riski; malnutrisyon ve malnutrisyon ve malnutrisyon riski olan gruplar arasında, ayrintılı geriatrik değerlendirme parametreleri açısından farkl1lık devam edip edilmediği lojistik regresyon analizi ile değerlendirildi. Malnutrisyon riski olanlar, normal nutrisyonu olanlarla karşılaştırıldığında sadece Geriatrik depresyon skalası skoru, kalk ve yürü testi süresi, el kavrama gücü ve uykusuzluk şiddeti indeksi skorlarının arasındaki farklılığın devam ettiği saptand $1 \quad(p<0,05)$. Sadece malnutrisyon ya da malnutrisyon riski ve malnutrisyonu olan gruplar, normal nutrisyonu olanlarla karşılaştırıldığında ise tüm ayrıntılı geriatrik değerlendirme parametrelerinde anlamlılık devam etti $(\mathrm{p}<0,05)$.

MNA grupları arasında ortostatik hipotansiyon, sistolik ortostatik hipotansiyon, diastolik ortostatik hipotansiyon ve üriner inkontinans varlığı açısından gruplar arasında anlamlı fark saptanmaz iken $(p>0,05), 1$ y1l içindeki düşme varlığı açısından gruplar arasinda anlamlı fark saptand $1(\mathrm{p}<0,05) .1$ y1 içinde düşme sıklığı Grup 3'te en yüksek oranda saptanırken Grup 1'de en düşük düzeydeydi $(p<0,05)$. 
Tablo 1. MNA grupları ile yaş, ilaç sayısı, VKİ ve laboratuvar verileri arasındaki ilişkinin değerlendirilmesi

\begin{tabular}{|c|c|c|c|c|}
\hline & $\begin{array}{c}\text { Grup 1 } \\
\text { MNA > 23,5 } \\
(\mathrm{n}: 308)\end{array}$ & $\begin{array}{c}\text { Grup 2 } \\
\text { MNA :17-23,5 } \\
\text { (n:154) }\end{array}$ & $\begin{array}{c}\text { Grup 3 } \\
\text { MNA }<17 \\
(\mathrm{n}: 44)\end{array}$ & $\mathbf{P}$ değeri \\
\hline Yaş (Y1l) & $75,89 \pm 6,74$ & $78,67 \pm 7,07$ & $81,90 \pm 6,52$ & $\mathbf{0 , 0 0 1}$ \\
\hline VKİ $\left(\mathrm{Kg} / \mathrm{m}^{2}\right)$ & $32,98 \pm 6,08$ & $32,16 \pm 6,32$ & $32,55 \pm 6,30$ & 0,043 \\
\hline İlaç sayıs1 & $5,85 \pm 3,03$ & $6,76 \pm 2,98$ & $6,85 \pm 3,71$ & 0,005 \\
\hline Glukoz (mg/dL) & $156,88 \pm 69,74$ & $159,98 \pm 79,3$ & $169,38 \pm 87,51$ & 0,633 \\
\hline HbAlc (\%) & $7,68 \pm 1,65$ & $7,42 \pm 1,70$ & $6,82 \pm 1,52$ & 0,012 \\
\hline Trigliserid (mg/dL) & $186,78 \pm 107,96$ & $183,70 \pm 154,81$ & $150,83 \pm 65,4$ & 0,382 \\
\hline LDL-Kolesterol (mg/dL) & $119,92 \pm 42,65$ & $127,26 \pm 41,55$ & $111,32 \pm 44,69$ & 0,152 \\
\hline HDL-Kolesterol (mg/dL) & $48,41 \pm 20,76$ & $48,41 \pm 13,53$ & $43,92 \pm 11,51$ & 0,576 \\
\hline $\mathrm{Hb}(\mathrm{g} / \mathrm{dL})$ & $13,59 \pm 1,67$ & $12,77 \pm 1,65$ & $11,81 \pm 1,57$ & 0,001 \\
\hline TSH (mIU/L) & $1,86 \pm 2,42$ & $1,80 \pm 1,96$ & $1,90 \pm 2,11$ & 0,965 \\
\hline Folik asid (ng/mL) & $9,62 \pm 4,14$ & $8,83 \pm 3,90$ & $7,70 \pm 4,91$ & 0,022 \\
\hline Vitamin B12 (pg/mL) & $322,12 \pm 249,32$ & $382,60 \pm 363,32$ & $464,13 \pm 367,22$ & 0,006 \\
\hline Vitamin D (ng/mL) & $19,05 \pm 12,39$ & $22,07 \pm 18,25$ & $25,25 \pm 17,96$ & $\mathbf{0 , 0 3 6}$ \\
\hline
\end{tabular}

Hb: Hemoglobin; HbAlc: Glikolize hemoglobin; HDL-K: High-density lipoprotein-Kolesterol, LDL-Kolesterol: Low-density lipoprotein-Kolesterol; MNA: Mini Nutrisyonel Değerlendirme; TSH: Tiroid situmulan hormon; VKİ: Vücut kitle indeksi.

Tablo 2. MNA grupları ile geriatrik değerlendirme parametreleri arasındaki ilişkinin değerlendirilmesi

\begin{tabular}{lcccc}
\hline & $\begin{array}{c}\text { Grup 1 } \\
\text { MNA }>\text { 23,5 } \\
(\mathbf{n : 3 0 8 )}\end{array}$ & $\begin{array}{c}\text { Grup 2 } \\
\text { MNA:17-23,5 } \\
(\mathbf{n : 1 5 4 )}\end{array}$ & $\begin{array}{c}\text { Grup 3 } \\
\text { MNA }<\text { 17 } \\
(\mathbf{n : 4 4 )}\end{array}$ & P değeri \\
TGYA & $90,40 \pm 11,41$ & $83,02 \pm 17,49$ & $60,34 \pm 31,05$ & $\mathbf{0 , 0 0 1}$ \\
EGYA & $18,85 \pm 4,70$ & $15,04 \pm 6,37$ & $7,93 \pm 7,20$ & $\mathbf{0 , 0 0 1}$ \\
Tinetti Denge & $14,57 \pm 2,77$ & $12,59 \pm 4,11$ & $8,49 \pm 5,73$ & $\mathbf{0 , 0 0 1}$ \\
Tinetti Yürüme & $11,13 \pm 1,92$ & $9,71 \pm 3,27$ & $6,58 \pm 4,31$ & $\mathbf{0 , 0 0 1}$ \\
Tinetti Total & $25,74 \pm 4,36$ & $22,31 \pm 7,01$ & $15,01 \pm 9,97$ & $\mathbf{0 , 0 0 1}$ \\
GDS & $3,29 \pm 3,45$ & $7,21 \pm 4,24 *$ & $8,21 \pm 4,24$ & $\mathbf{0 , 0 0 1}$ \\
MMSE & $25,82 \pm 3,10$ & $23,67 \pm 4,65$ & $21,49 \pm 6,08$ & $\mathbf{0 , 0 0 1}$ \\
KYT (sn) & $12,44 \pm 6,64$ & $17,27 \pm 10,13 *$ & $31,44 \pm 29,02$ & $\mathbf{0 , 0 0 1}$ \\
EKG (Kg) & $24,1 \pm 8,77$ & $18,20 \pm 6,49 *$ & $12,33 \pm 7,09$ & $\mathbf{0 , 0 0 1}$ \\
UŞI & $12,07 \pm 9,06$ & $16,41 \pm 8,80 *$ & $18,27 \pm 9,01$ & $\mathbf{0 , 0 0 2}$ \\
\hline
\end{tabular}

EGYA: Enstrümantal günlük yaşam aktiviteleri; EKG: El kavrama gücü; GDS: Geriatrik depresyon skalası, KYT: Kalk ve yürü testi; MMSE: Mini Mental Durum Değerlendirme; MNA: Mini Nutrisyonel Değerlendirme; TGYA: Temel günlük yaşam aktiviteleri; Uşi: Uykusuzluk şiddeti indeksi.

*Yaşın etkisi ortadan kaldırlan Lojistik regresyon analizi sonrasında, malnutrisyon riski ile normal nutrisyon arasındaki anlamlılı̆̆ı devam ettiği parametreleri $(p<0,05)$.

\section{Tartışma ve Sonuç}

Çalışmamızda yaşlı diyabetik hastalarda malnutrisyon ve malnutrisyon riski prevelans1 sirasiyla $\% 8,7$ ve $\% 30,43$ olarak saptand. Diyabetik yaşlı hastalarda malnütrisyon ile fonksiyonellik, yürüme ve denge fonksiyonları, kognisyon, duygu durum, el kavrama gücü ve uyku durumu üzerine anlamlı oranda olumsuz etkilerinin olduğu saptandi.

Malnutrisyon, besin emilimindeki yetersizlik ve/veya besin alımında azalma ile karakterize olup bu durum tedavi edilmezse veya tedavi ertelenirse, fiziksel ve mental fonksiyonlarda 
düşüş, yaşam kalitesinde bozulma, kırılganlık, hastane başvurularında artış ve uzun hastane yatış süreleri gibi fiziksel ve psikososyal sonuçlara yol açabilen bir geriatrik sendromdur $(21,22)$. Genç diyabetik hastalarda tip $2 \mathrm{DM}$ ortaya çıkışı genellikle obezite ve insülin direncine bağlı olduğu için optimal glisemik kontrol için güncel tedavi yaklaşımı yaşam tarzı modifikasyonu ve ilaç tedavisidir (23). Ancak bu yaklaşım diyabetik yaşl1 hastalarda malnutrisyonla sonuçlanabilir. Yaşlanmanın kendisi vücut ağırlığı ve gida alımında azalma ile ilişkili olabileceğinden (24) diyabetik olan ve olmayan yaşlı hastalarda malnutrisyon prevelansı yüksek olarak görüldüğü bilinmektedir (25). Çalışma grubumuzda malnutrisyon ve malnutrisyon riski prevalansı sırasıyla $\% 8,7$ ve $\% 30,43$ idi. Diyabetik yaşlı hastalarda malnutrisyon ve malnutrisyon riski varlığ 1 klinik pratikte sıklıkla göz ardı edilse de çalışma sonuçlarımıza göre oldukça yüksek prevalansa sahip olduğu görülmektedir. Literatür incelendiğinde; 146 geriatrik diyabetik hastanın prospektif olarak değerlendirildiği bir çalışmada malnutrisyon ve malnutriyon riski prevelansı bizim çalışmamızdan yüksek saptanmıştır (sırasıyla \%13,9 ve \%75) (26). $\mathrm{Bu}$ farklılık bahsedilen çalışmada nutrisyonel durumun MNA-kısa form ile değerlendirilmiş olduğundan ve yaş ortalamasının $82,5 \pm 7,3$ yıl olmasından kaynaklanıyor olabilir.

Çalışma sonuçlarımıza göre, yaşlı diyabetik hastalarda malnutrisyonu olan grupta $\mathrm{HbA} 1 \mathrm{c}$ düzeyi anlamlı olarak düşük saptandı. Ulaşılan bu sonuç iyi glisemik kontrolün işaretlerinden biri olarak kullanılan $\mathrm{HbA} 1 \mathrm{c}$ düzeyinin geriatrik yaş grubunda malnutrisyonun da işaretlerinden biri olabileceği yönündeki verileri desteklemektedir (26). Yapılan bu prospektif gözlemsel çalışmada, glisemik ve nutrisyonel parametreleri değerlendirilmiş olup iyi glisemik kontrol (HbAlc <\%7,5) durumundaki hastalarda MNA skorlarının ve VKİ'nin anlamlı derecede düşük olduğu saptanmıştır. Başka bir çalışmada ise, hastanede yatarak tedavi gören diyabetik olmayan yaşlı hastalarda düşük insülin direncinin malnutrisyonla ilişki olduğu gösterilmiştir (27). Malnutriyon riski ve malnutrisyon gruplarında ortalama kan şekeri düzeyi kontrol grubuna göre anlamlı olarak yüksek olmasına rağmen $\mathrm{HbA1c}$ daha düşük bulunmuştur $\quad(p<0,05) . \quad \mathrm{Bu} \quad$ durum malnütrisyon ve malnutrisyon riski gruplarında $\mathrm{Hb}$ düzeyinin normal nutrisyon grubuna göre anlamlı olarak daha düșük saptanmasından kaynaklanabilir. Diğer yandan malnutrisyon, $\mathrm{HbAlc}$ değerlerinde azalmaya ve muhtemelen düşük insülin direncinin bir sonucu olarak oral hipoglisemik tedavi gereksinimlerinin azalmasına katkıda bulunabilir.

Miknonutrient eksiklikleri Tip 2 DM olan hastalarda ve yaşlı hastalarda sık olarak görülmektedir. Tip 2 DM olan hastalarda B12 vitamin eksikliği \%22 (28) ve D vitamin eksikliği \%85-90 (29) siklıkta görüldüğü bildirilmiştir. Yaşlı hastalarda özellikle malnutrisyon varlığında B12 vitamin, folik asit ve D vitamin eksikliği sık olarak görülmektedir (30). Çalışma verilemiz mikronutrient düzeyleri açısından değerlendirildiğinde malnutrisyon grubunda serum folat düzeyi anlamlı olarak düşük iken serum B12 vitamini ve serum $25(\mathrm{OH})$ D vitamini düzeyi anlamlı olarak yüksek idi. Bunun sebebi serum vitamin B12 ve serum $25(\mathrm{OH})$ D vitamini düzeylerinin, birinci basamak sağlık kuruluşlarında rutin olarak değerlendirilmesi ve replasman tedavilerinin başlanması ya da diyabetik polinöropati tedavisinde bazen vitamin b12 preperatlarının kullanılması olabilir.

Malnutrisyon fonksiyonellikte bozulma, mobilite bozukluğu, düşme, kognitif bozukluk, sarkopeni, duygu durum ve uyku bozuklukları gibi çok sayıda komplikasyona yol açabilen bir geriatrik sendrom olarak bilinmektedir (31,32). Yaşlı diyabetik hastalarda da malnutrisyonu olanlarda bu komplikasyonların gelişebileceği yapılan çalışmalarda gösterilmiştir. Örneğin, diyabetik yaşlı hastalar ile yapılan çalışmalarda malnutrisyonu olan hastalarda retinopati, periferal nöropati ve nefropati gibi mikrovasküler komplikasyonların da katkısıyla fonksiyonellikte gerileme ve sarkopeniye yol açabileceği bildirilmiştir (25, 33 , 34). Ayrica bu hastalarda inflamatuar sitokinler, komorbiditeler, malnutrisyon ve düşük fiziksel aktivitenin kas kitlesinde kayıp, kas gücü ve fonksiyon kaybı ile yürümedenge bozuklukları ve düşmelere yol 
açabileceği bilinmektedir (35). Vasküler endotelyal disfonksiyon, inflamasyon, kan beyin bariyer hasarn, demyelinasyon ve aksonal kayıp gibi nedenlerden dolayı yaşlı diyabetik hastalarda kognitif fonksiyonlar da olumsuz etkilenmektedir (36). Kognitif disfonksiyonun ise hastaları özellikle ilerleyen yaş ile malnutrisyon riski ile karşı karşıya getirdiği bilinmektedir (37). Nokturmal solunum bozukluklarının tekrarlayan oksijen desatürasyonu ve uyku bölünmelerine yol açarak glukoz metabolizma bozukluklarına yol açabileceği gösterilmiştir (38). Özellikle yaşlılarda uyku bozuklukları iştahı, gıda alımını, melatonin salınımını ve sirkadyen ritmi etkileyerek malnutrisyon ile sonuçlanabilir $(17,32)$. Çalışma sonuçlarımız tüm bu verileri destekler nitelikte olup yaşlı diyabetik hastalarda malnutrisyon varlığının, yürüme ve denge fonksiyonları, kognitif durum, duygu durum, el kavrama gücü ve uyku durumunun da dahil olduğu tüm geriatrik değerlendirme parametrelerini olumsuz etkilediği gösterilmiştir. Diğer çalışmalardan farklı olarak bahsedilen tüm geriatrik değerlendirme parametreleri tek bir çalışmada değerlendirilip malnutrisyonun yaşlı diyabetik hastalardaki olumsuz etkileri ortaya koyulmuştur.

\section{KAYNAKLAR}

1. Zheng Y, Ley S, Hu F. Global aetiology and epidemiology of type 2 diabetes mellitus and its complications. Nat Rev Endocrinol. 2018;14, 8898.

2. Kirkman MS, Briscoe VJ, Clark N, et al. Consensus Development Conference on Diabetes and Older Adults. Diabetes in older adults: a consensus report. $J$ Am Geriatr Soc. 2012;60:2342-56.

3. Resnick B, Boltz M. Optimizing Function and Physical Activity in Hospitalized Older Adults to Prevent Functional Decline and Falls. Clin Geriatr Med. 2019;35:237-51.

4. Abada S, Clark LE, Sinha AK, et al. Medication Regimen Complexity and Low Adherence in Older Community-Dwelling Adults With Substantiated Self-Neglect. J Appl Gerontol. 2019 ;38:866-883

5. Sircar M, Bhatia A, Munshi M. Review of Hypoglycemia in the Older Adult: Clinical Implications and Management. Can J Diabetes. 2016;40:66-72.
Çalışmamızın güçlü yanları yüksek örneklem sayısı, tüm hastalara ayrıntılı geriatrik değerlendirme testleri yapılması ve komorbid hastalıkların değerlendirilmesidir. Çalışmanın belli noktalarda kisitlilikları mevcuttur. Bunlardan en önemlisi çalışmanın kesitsel ve retrospektif bir çalışma olmasıdır. Diğer yandan DM tedavisinde kullanılan ilaçların ve hastanın almakta olduğu mikronutrient replasman tedavilerinin değerlendirilmemesi k1sitl11ıklar olarak değerlendirilebilir.

\section{Sonuç}

Çalışma sonuçlarımız yaşlı diyabetik hastalarda malnütrisyonun fonksiyonel gerileme, yürüme ve denge bozukluklarl, kognisyon ve duygu durum bozuklukları, el kavrama gücünde azalma ve uyku bozuklukları için bir risk faktörü olabileceğini göstermektedir. Yaşlı diyabetik hastalarda DM tedavi ilkeleri gözetilirken nutrisyonel değerlendirmenin yapılması gerekmektedir. Yaşlı diyabetik hastalarda sık1 diyet kontrolünün malnutrisyon ve malnutrisyon ilişkili sağlık sorunları ile sonuçlanabileceği akılda bulundurulmalıdır. Zaten duyarlı olan yaşlı diyabetik hastaların nutrsiyonel açıdan değerlendirilmesi ve malnutrisyonun taranması, erken dönemde tanınması ve tedavisi önemlidir.

6. Corish CA, Bardon LA. Malnutrition in older adults: screening and determinants. Proc Nutr Soc. 2019;78:372-379.

7. Dent E, Hoogendijk EO, Visvanathan R, et al. Malnutrition Screening and Assessment in Hospitalised Older People: a Review. J Nutr Health Aging. 2019;23:431-41.

8. Ülger Z, Halil M, Kalan I, et al. Comprehensive assessment of malnutrition risk and related factors in a large group of community-dwelling older adults. Clinical Nutrition. 2010;29, 507-11.

9. Di Francesco V, Pellizzari L, Corrà L, et al. The anorexia of aging: impact on health and quality of life. Geriatric Care. 2018;4.

10. Rizvi AA. Nutritional challenges in the elderly with diabetes. Int J Diabetes Mellit. 2009; 1: 2631.

11. Unutmaz GD, Soysal P, Tuven B, et al. Costs of medication in older patients: before and after comprehensive geriatric assessment. Clin interv aging. 2018;13, 607.

12. Durmaz B, Soysal P, Ellidokuz H, et al. Validity and reliability of geriatric depression scale-15 
(short form) in Turkish older adults. North clin Istanb. 2018;5, 216.

13. Morin CM, Belleville G, Bélanger L, et al. The Insomnia Severity Index: psychometric indicators to detect insomnia cases and evaluate treatment response. Sleep, 2011;34, 601-608.

14. Ates Bulut E, Soysal P, Dokuzlar O, et al. Validation of population-based cutoffs for low muscle mass and strength in a population of Turkish elderly adults. Aging Clin Exp Res. 2020;32:1749-55.

15. Dutoglu E, Soysal P, Smith L, et al. Nocturia and its clinical implications in older women. Arch Gerontol Geriatr. $2019 ; 85: 103917$.

16. Lanier JB, Mote MB, Clay EC. Evaluation and management of orthostatic hypotension. Am Fam Physician. 2011;84:527-36.

17. Soysal P, Smith L, Dokuzlar O, et al. Relationship between nutritional status and insomnia severity in older adults. $J$ Am Med Dir Assoc. 2019; 20, 15931598.

18. Bozoglu E, Isik AT, Doruk H, et al. The effects of early vitamin B12 replacement therapy on the cognitive and functional status of elderly subjects. Klin Psikofarmakol Bul. 2010;20:120-124.

19. Soysal P, Smith L, Capar E, et al. Vitamin B12 and folate deficiencies are not associated with nutritional or weight status in older adults. Exp Gerontol. 2019;116, 1-6.

20. Dawson-Hughes B, Mithal A, Bonjour JP, et al. IOF position statement: vitamin D recommendations for older adults. Osteoporos Int, 2010;21, 1151-1154.

21. Lorenzo-Lopez L, Maseda A, de Labra C, et al. Nutritional determinants of frailty in older adults: a systematic review. BMC Geriatr. 2017;17:108.

22. Soysal P, Veronese N, Arik F, et al. Mini Nutritional Assessment Scale-Short Form can be useful for frailty screening in older adults. Clin Interv Aging, 2019;14, 693.

23. American Diabetes Association. Executive summary: standards of medical care in diabetes 2008. Diabetes Care, 2008; 31: S5-S11.

24. Wakimoto P, Block G. Dietary intake, dietary patterns and changes with age: an epidemiological perspective. J Gerontol A Biol Sci Med Sci. 2001; 56: $65-80$

25. Turnbull PJ, Sinclair AJ. Evaluation of nutritional status and its relationship with functional status in older citizens with diabetes mellitus using the mini nutritional assessment (MNA) tool—a preliminary investigation. $J$ Nutr Health Aging. 2002; 6: 18589.

26. Vischer UM, Perrenoud L, Genet $\mathrm{C}$, et al. The high prevalence of malnutrition in elderly diabetic patients: implications for anti-diabetic drug treatments. Diabetic Medicine, 2010;27, 918-24.

27. Bonin-Guillaume S, Herrmann FR, Boillat D, et al. Insulinemia and leptinemia in geriatric patients: markers of the metabolic syndrome or of undernutrition?. Diabetes Metab. 2006; 32: 236243.

28. Pflipsen MC, Oh RC, Saguil A, et al. The prevalence of vitamin B12 deficiency in patients with type 2 diabetes: a cross-sectional study. $\mathrm{J} \mathrm{Am}$ Board Fam Med, 2019; 22:528-34.
29. Kaidar-Person O, Person B, Szomstein S, et al. Nutritional deficiencies in morbidly obese patients: a new form of malnutrition? Part A: vitamins. Obesity Surgery, 2008;18:870-76.

30. Efendioğlu EM, Göl M, Tarakçıoğlu MS, et al. Determination of Vitamin D, Vitamin B12 and Folic Acid Deficiency Prevalence Among Geriatric Palliative Care Patients. Eur J Geriatr Gerontol. 2020;2:9-12.

31. Iş̧1k AT, Soysal P. Sendrom, Geriatri ve Geriatrik Sendrom. Soysal P, Işık AT, edt, In: Geriatri Pratiğinde Geriatrik Sendromlar 1. bask1, İzmir, US Akademi, 2018. p. 7-50.

32. Heybeli C, Soysal P, Oktan MA, et al. Associations between nutritional factors and excessive daytime sleepiness in older patients with chronic kidney disease. Aging Clin Exp Res, 2021;1-9.

33. Liu GX, Chen Y, Yang YX, et al. Pilot study of the Mini Nutritional Assessment on predicting outcomes in older adults with type 2 diabetes. Geriatr Gerontol Int, 2017; 17, 2485-92.

34. Velázquez-Alva MC, Irigoyen-Camacho ME, Zepeda-Zepeda MA, et al. Sarcopenia, nutritional status and type 2 diabetes mellitus: A crosssectional study in a group of Mexican women residing in a nursing home. Nutr Diet, 2020;77, 515-22.

35. Jang HC. Sarcopenia, frailty, and diabetes in older adults. Diabetes Metab J. 2016; 40: 182-9.

36. Biessels GJ, Despa F. Cognitive decline and dementia in diabetes mellitus: mechanisms and clinical implications. Nat Rev Endocrinol. 2018;14:591-604.

37. Mantzorou M, Vadikolias K, Pavlidou E, et al. Nutritional status is associated with the degree of cognitive impairment and depressive symptoms in a Greek elderly population. Nutr Neurosci, 2020;23, 201-9.

38. Keckeis M, Lattova Z, Maurovich-Horvat E, et al. Impaired glucose tolerance in sleep disorders. PLoS One 2010;5:e9444. 